\title{
COMMUNICATION
}

\section{Bacterial Formation of Benzoic Acid in Milk}

\author{
(Received December 25, 1967) \\ Takao NISHIMOTO*, Masahiko UYETA*, Sakae TAUE*
and Ikuo TAKEBAYASHI*
}

(Kochi Pref. Public Health Lab.: Kochi, Japan)

Recently, microbial formation of aromatic acids such as trans cinnamic acid from phenylalanine ${ }^{1)}$, $p$-cumaric acid from tyrosine ${ }^{2)}$ has been reported. It has been also known for a long time that salicylic acid was formed from indol, alkyl benzene, naphthalene, anthracene and phenanthrene by microorganisms ${ }^{3}$, however, bacterial formation of benzoic acid in milk has not been reported yet. In the course of our investigation on the benzoic acid in ferment milk ${ }^{4}$, it was found that some strains of Lactobacillus species were able to produce benzoic acid in milk medium

Cultivation was carried out for 5 days at $37^{\circ} \mathrm{C}$ in the medium of $15 \%$ dry skim milk solution. The time course of culturing of Lact. acidophilus and Lact. bulgaricus in skim milk medium was

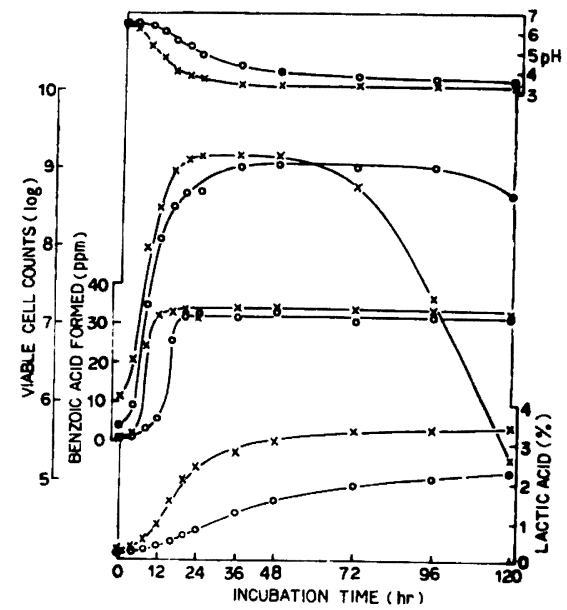

Fig. 1. Time course of Lact. acidophilus ( $\bigcirc-\bigcirc)$ and Lact. bulgaricus $(\times-\times)$ cultured in skim milk medium

* 西本孝男, 上田雅彦, 田植栄, 竹林生夫（高知県 衛生研究所) shown in Fig. 1. Both strains of Lactobacillus were found to produce approximately $30 \mathrm{ppm}$ of benzoic acid at logarithmic phase of the growth.

Benzoic acid produced in the medium was determined by gas chromatographys) and isolated in fine crystals after extraction and identified by melting point $\left(121.0 \sim 121.8^{\circ} \mathrm{C}\right)$ and infrared absorption spectra. The gas chromatograms of extract of medium were shown in Fig. 2 and the infrared spectra of isolated products were shown in Fig. 3.

The precursor of benzoic acid in milk medium and formation of benzoic acid by another bacteria has not been found at present. These problems are now under investigation.
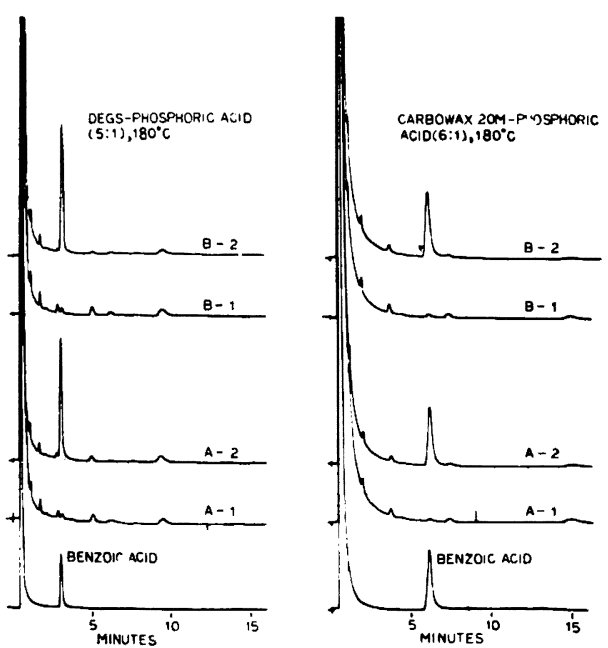

Fig. 2. Gas chromatograms of extract of medium, before and after cultivation A-1: before culture of $L$. acidophilus A-2: after culture of L. acidophilus for $24 \mathrm{hr}$ B-1: before culture of $L$. bulgaricus B-2: after culture of $L$. bulgaricus for $24 \mathrm{hr}$ 


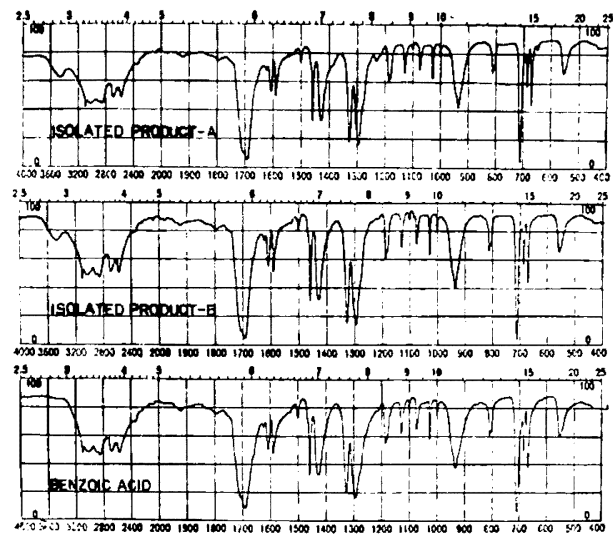

Fig. 3. Infrared spectra of benzoic acid and isolated products

Isolated product-A: extracted from the culture medium of $L$. acidophilus

Isolated product-B: extracted from the culture medium of $L$. bulgaricus

\section{References}

1) K. Ogata, K. Uchiyama, H. Yamada: Agr. Biol. Chem. 31, 200 (1967).

2) K. Ogata, K. Uchiyama, H. Yamada: ibid. 31, 600 (1967).

3) Y. Sakamoto, U. Uchida, K. Ichihara: Med. J. Osaka Univ. 3, 447, 487 (1953); V. Treccani: Ann. Microbiol. 5, 232 (1953); M.H. Rogoff, I. Wender: J. Bacteriol. 73, 264 (1957).

4) T. Nishimoto, M. Uyeta: Shokuhin Eiseigaku Zasshi 9, 60 (1968).

5) T. Nishimoto, M. Uyeta: ibid. 6, 231 (1965); 8, 118 (1967). 